
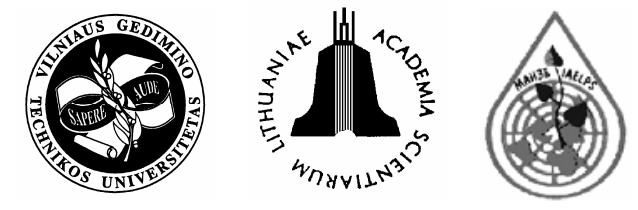

\title{
EXPERIMENTAL INVESTIGATION INTO TOXIC IMPACT OF ROAD MAINTENANCE SALT ON GRASS VEGETATION
}

\author{
Pranas Baltrènas ${ }^{1}$, Agnė Kazlauskiené $\dot{e}^{2}$, Jolita Zaveckyté $\dot{~}^{3}$ \\ Dept of Environmental Protection, Vilnius Gediminas Technical University, \\ Sauletekio al. 11, LT-10223 Vilnius, Lithuania.

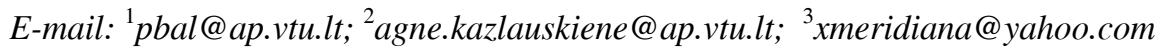 \\ Submitted 8 Mar 2006; accepted 25 Mar 2006
}

\begin{abstract}
Plants experience a number of stresses in the environment, including those caused by salts, drought, heavy metals and frost. To maintain safety during winter, deicing salt (sodium chloride) is sprinkled over roads. In global practice, natural and laboratory investigations of the impact of road maintenance salts on various species of plants are carried out. So far in Lithuania, only single cases of such investigations have occurred.

The aim of this investigation is to determine which of the analysed herbaceous vegetation species (perennial ryegrass, fescue grass, meadow-grass) shows the highest degree of resistance to toxic impact of salts (stress), to set the toxic limits of salt concentrations and to analyse how salts impact on the core parameters of herbaceous vegetation.

The investigation proves that $\mathrm{NaCl}$ content in the soil negatively affects the growing process of grass vegetation, i e it slows down increase of its above-ground part and reduces its phytomass. During experiments it was determined that perennial ryegrass had the highest degree of resistance to toxic impact of salts.
\end{abstract}

Keywords: road maintenance salts, herbaceous vegetation species, toxicity.

\section{Introduction}

To ensure safe motor traffic in wintertime, salts (most frequently sodium chloride) are used on roads. First of all, chlorides get onto the driving part and roadsides and directly contaminate the soil of protective areas located on waysides and negatively affect flora. In addition, there is indirect pollution of the environment when atmospheric precipitation or melt-water wash salts out of the soil to surface and ground waters [1].

In global practice, natural and laboratory investigations into the impact of road maintenance salts on various species of plants are carried out. So far in Lithuania, only single cases of such investigations have occurred.

Seeking to determine a negative effect of technical salts on the ecosystems in the environment of roads, Department of Environment Protection of Vilnius Gediminas Technical University investigated the impact of road maintenance salts on water ecosystems according to diatom flora investigation in the Verkiai pond and the Gineitiškiai lake in 2004. The investigation findings show that one of the reasons that could impact on the spread of diatom flora typical to salty waters is road maintenance salts (chlorides) [2].

Plants experience a number of stresses in the environment, including those caused by salts, drought, heavy metals, and frost.

Soil salinity is an important factor causing abiotic stress on the global scale. Presently, around half of all irrigated soils are affected by salt content. High salt concentration causes ionic imbalance and increases osmotic shock in plants $[3,4]$.

In order to determine the causes of forest biomass reduction, various factors were investigated. Based on previous research, pollutant emissions are among the causes reducing the amount of spruces $(P$. abies) growing up to their maturity in Europe. Road salt is also an obvious and possible cause of tree amount reduction.

When the condition of blue spruces started deteriorating in Japan, investigation into spruce decay causes was started in 2003. Major part of forest areas consists of coniferous species, such as Picea abies, Picea glehnii and Abies sachalinensis. One third of $P$. abies and $P$. glehnii by roadsides started growing slower. It is known that the species of blue spruce is very sensitive to salts compared to other species.

Upon having compared the characteristics of damaged and unharmed areas of $P$. abies and $P$. glehnii growth in north Japan, it was noticed that a tree height in areas damaged by salts was smaller compared to unpolluted areas. Detected sodium and chlorine ions migrate to needles. Furthermore, the cast of needles in damaged areas was more rapid, and the velocity of photosynthesis, water potential and velocity of evaporation were slower compared to non-contaminated areas. These changes in physiological parameters are the same as those in plants saturated with salts. Consequently, a conclusion can be drawn that, in the course of time, salts contained in the 
soil accumulate in needles, disturb various physiological properties and finally suppress the growth of trees as a result of general complex phenomena. Investigation into sodium and chlorine impact causing these symptoms shows that chlorine has a higher negative effect than sodium [5].

In Finland, the accumulation and visual damage of salt made to the needles of Scots pine (Pinus sylvestris) was investigated in 1992-1994. Two specimen sections, $4 \mathrm{~km}$ each, separated by a highway, were selected in eastern Finland for study. In Savo-Karjala region the use of road salt was reduced by around one tenth (areas with a low salt content), whereas in the central region of Finland road salt was used in a usual manner (areas with a high salt content). Needles, aged from one to two years, were investigated 8 times over the period of 1992-1994. The findings showed visual damage in pine needles. The concentrations of sodium, chlorine and calcium were also analysed. Reduction of salt use over 2 years clearly decreased accumulation of salt $\left(\mathrm{Na}^{+}\right.$and $\left.\mathrm{Cl}^{-}\right)$, and visual damage to the growth of pine needles was determined in the areas located closer to roadsides. Calcium concentration in needles was not changing. In the specimen areas, along the places with a high salt content, needle browning and premature fall, especially in late spring, were recorded. Harmful effect of road salts covered not a bigger distance than (20-30) $\mathrm{m}$ from the road, and salt concentration and visual harm in needles were insignificant beyond this distance. Taking into consideration the fact that salt concentration in the soil was not changing very much, salt spatters reaching trees through the air is an important factor of salt accumulation in needles. Changes of the air conditions have a significant impact on salt accumulation in needles and cause visual harm. Big temperature fluctuations intensify a negative impact of salts on needles.

Salt concentration in pine needles was higher in late winter, March and April. Even though the use of salt was discontinued in April, the concentration of sodium and chlorine in needles, especially in those aged one and two years, remained clearly higher in April than in May and June. Sodium and chlorine concentration in needles decreases in the summertime but it still remains higher than in autumn. Salt accumulation in needles increases with the age of needles.

$\mathrm{Na}^{+}$and $\mathrm{Cl}^{-}$accumulation in needles has different velocities. The accumulation indirectly depends on salt use on roads. This shows a different scheme of $\mathrm{Na}^{+}$and $\mathrm{Cl}^{-}$getting onto needles, accumulation and washing out in needles.

It is stated that salt use slows down the growth of pines on roadsides. It was noticed that even a small amount of road salts may be significant for salt accumulation in trees growing in the nearest proximity to roadsides.

Visual harm was observed in up to $2,5 \mathrm{~m}$ tree height. This is an approximate height that is reached by salt spatters through the air.

It was also determined that salts can have indirect impact on the spread of diseases of trees growing closer to roadsides, such as needle cast fungus (Lophodermium seditiosum) and pine aphid (Cinara pinea) [6].

In Spain, the impact of three kinds of chlorine salts (15 $\mathrm{mol} / \mathrm{m}^{-3} \mathrm{CaCl}_{2}, 30 \mathrm{~mol} / \mathrm{m}^{-3} \mathrm{NaCl}$ and $30 \mathrm{~mol} / \mathrm{m}^{-3}$ $\mathrm{KCl}$ ) on Carrizo citruses (Citrus sinensis and Poncirus trifoliata) and Cleopatra mandarins (Citrus reshni) seedlings was investigated in 1998. Carrizo seedlings showed stronger growth, higher phenotype and average sensitivity to salt content compared to Cleopatra seedlings, which were growing slower and were more tolerant to salts. It was determined that $\mathrm{Cl}^{-}$slowed down the growth and gas circulation parameters, caused anatomic damages and mineral imbalance in seedlings. The first study proved that chlorine ions restricted the growth of citruses. But later investigations determined that damage might be caused by any ion-chlorine and sodium or by both of them $[7,8]$.

In the United States of America (the State of India$n a)$ investigation into the impact of $\mathrm{NaCl}$ used in winter on peat moss (Sphagnum recurvum) was carried out in 1984. A bog located near to Indiana Toll road crossing Pinhook Bog was chosen for study. One of more noticeable peat moss was studied in the bog. The investigation showed that salt concentrations contained within (300-1500) mg/l limits, expressed as $\mathrm{Cl}^{-}$, considerably reduced the growth of Sphagnum recurvum lengthways under laboratory conditions. Biomass growth was also decreased at high $\mathrm{Cl}^{-}$concentrations. The results showed that chlorine was a stronger growth inhibitor compared to sodium. During experiments, where contact with water was reduced and the surface area of plant evaporation was increased, salt concentrated in plant tops because of total evaporation, and this resulted in the death of plants at different $\mathrm{NaCl}$ concentrations. Plant watering by imitating rain removed salt cover from the plants but peat mosses developed rapidly again and repeated the same decay effects in the period of 3 weeks after the last watering. The growth reduction and decay of Sphagnum recurvum peat moss revealed a possible impact of set $\mathrm{NaCl}$ concentrations in Pinhook Bog on peat mosses in the area impacted by road salts [9].

In Switzerland, the impact of road salts on flora was investigated during drought in 1984. A hawthorn ( $\mathrm{Cra}$ taegus spp.) was chosen for study. In order to simulate the impact of road salt spatters on flow nearby roadsides hawthorn plants were exposed to $\mathrm{NaCl}$ spatters in winter. The use of $\mathrm{NaCl}$ significantly increased non-resistance of hawthorns to green apple aphid Aphis pomi. An average degree of drought also reduced aphid population. Road salt and drought even of a low degree have major impact on the increase of aphid population by roadsides [10].

\section{Investigation methods and conditions}

The investigation was carried out under laboratory conditions.

The aim of investigation: to determine which of the analysed herbaceous vegetation species (perennial ryegrass, fescue grass, meadow-grass) shows the highest degree of resistance to toxic impact of salts (stress), to set the toxic limits of salt concentrations, and to analyse how 
salts impact on the core parameters of herbaceous vegetation.

Three kinds of grass vegetation, most frequently used in Lithuania for planting on waysides, were selected:

- $\quad$ Perennial ryegrass (darimo species) - Lolium perenne L.;

- $\quad$ Fescue grass (prana species) - Festuca pratensis Huds.;

- $\quad$ Meadow-grass (balin species) - Poa pratensis L.

Road maintenance salt widely applied in Lithuania, i e crushed technical $\mathrm{NaCl}$, treated with potassium ferrocyanide $-\left(\mathrm{K}_{4}\left[\mathrm{Fe}(\mathrm{CN})_{6}\right]\right)$, was used in this investigation.

The course of investigation: 100 seeds of perennial ryegrass, fescue grass and meadow-grass, each were sown in plastic plant pots containing $1 \mathrm{~kg}$ of soil. Three $\mathrm{NaCl}$ concentrations $-20 \mathrm{~g} / \mathrm{kg}, 10 \mathrm{~g} / \mathrm{kg}$ and $1 \mathrm{~g} / \mathrm{kg}$, in the form of solutions inserted into the soil, were used in the study. In this way the three mentioned species of grass vegetation were seeded into 12 plastic: each species was seeded in 3 pots with different $\mathrm{NaCl}$ salt concentrations in soil and in uncontaminated soil (control plants).

The bottom of each plant pot had holes to ensure natural water run-off and prevent excess accumulation of water. The seeds of each species were simultaneously seeded in a medium contaminated with sodium chloride salt and in a pure medium (experimental and control plants). Both the experimental and the control plants were grown under identical conditions, i e at the same temperature and lighting, were watered with identical amounts of water and at the same time.

The study determined the main parameters of grass vegetation, i e the length of above-ground part $(\mathrm{cm})$ and plant's phytomass (mg).

Room temperature $\left({ }^{\circ} \mathrm{C}\right)$ was observed during investigation. The experimental and control plants were watered, taking into consideration the room air temperature and visual soil humidity, once a week: with $50 \mathrm{ml}$ of water for the first 3 weeks, with $100 \mathrm{ml}$ starting work week 4. Experimental plants were grown in the northern part of the laboratory without direct sunlight, ie unfavourable ecological conditions were chosen.

\section{Investigation findings}

During the first week of study ryegrass and fescue grass germinated, whereas meadow-grass did not germinate even in the control plant pot. During the first week of growth $17-18{ }^{\circ} \mathrm{C}$ temperature was maintained in the room. The diagram shows that after the first week ryegrass had a bigger length of the above-ground part than fescue grass. The length of ryegrass in the soil with $1 \mathrm{~g} / \mathrm{kg} \mathrm{NaCl}$ content showed the difference of 2,6 times, that of fescue grass $-2,5$ times compared to the control one (Fig 1).

During the second week of study meadow-grass started germinating. The room temperature was raised to 22 $23{ }^{\circ} \mathrm{C}$. The increased room temperature resulted in a considerable growth of plants during the second week. The length of ryegrass control plants amounted to $13,2 \mathrm{~cm}$, that of fescue grass $-11,5 \mathrm{~cm}$ and of meadow-grass $2,8 \mathrm{~cm}$. The length of the above-ground part of ryegrass in the soil with $1 \mathrm{~g} / \mathrm{kg} \mathrm{NaCl}$ content showed the difference of 1,4 times, that of fescue grass $-2,0$ and of meadowgrass - 2,2 times compared to the control one. On the second week the difference between ryegrass lengths in contaminated soil and in control one was much smaller (Fig 2).

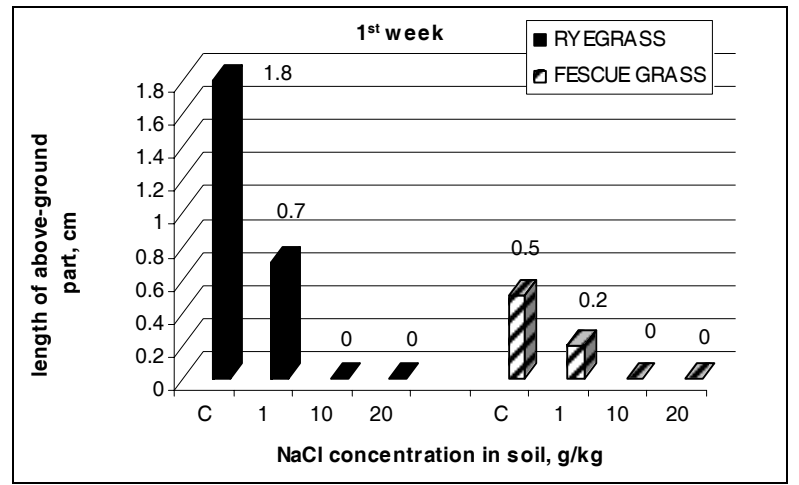

Fig 1. Length of above-ground part of grass vegetation after the $1^{\text {st }}$ week of growth (meadow-grass did not germinate)

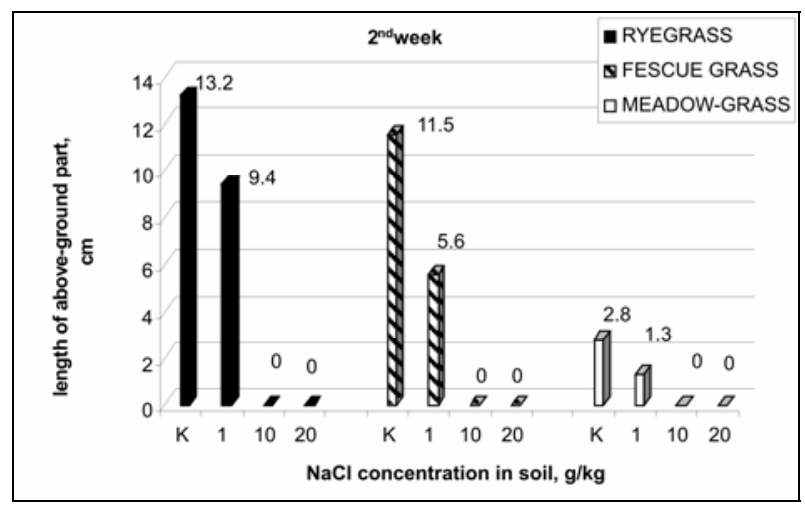

Fig 2. Length of above-ground part of grass vegetation after the $2^{\text {nd }}$ week of growth

The biggest increase of the ryegrass above-ground part occurred on the second week of growth, when it enlarged from $1,8 \mathrm{~cm}$ to $13,2 \mathrm{~cm}$ in the control soil, and from $0,7 \mathrm{~cm}$ to $9,4 \mathrm{~cm}$ in the polluted soil. This was the result of temperature increase from $17^{\circ} \mathrm{C}$ to $23{ }^{\circ} \mathrm{C}$ in the room. Difference between control and experimental plants after the $1^{\text {st }}$ week of growth was $1,1 \mathrm{~cm}$, after the $2^{\text {nd }}$ week $-3,8 \mathrm{~cm}$, after the $3^{\text {rd }}$ week $-5,6 \mathrm{~cm}$, the $4^{\text {th }}$ week $-8,6 \mathrm{~cm}$.

A maximum increase of the above-ground part of fescue grass, like that of ryegrass, occurred during the $2^{\text {nd }}$ week of growth, when it grew up from $0,5 \mathrm{~cm}$ to $11,5 \mathrm{~cm}$ in the control soil, from $0,2 \mathrm{~cm}$ to $5,6 \mathrm{~cm}$ in the contaminated soil. Difference between control and experimental plants after the $1^{\text {st }}$ week of growth made up $0,3 \mathrm{~cm}$, after the $2^{\text {nd }}$ week $-5,9 \mathrm{~cm}$, after the $3^{\text {rd }}$ week $5,1 \mathrm{~cm}$, the $4^{\text {th }}$ week $-6,9 \mathrm{~cm}$.

Meadow-grass germinated one week later compared to ryegrass and meadow-grass, i e after the $2^{\text {nd }}$ week of experiments, the above-ground length of control plants had reached $2,8 \mathrm{~cm}$, and that of experimental ones - 
$1,3 \mathrm{~cm}$ (the difference makes up 1,5 cm). Starting from the $3^{\text {rd }}$ experimental week, difference between control and experimental mead-grass plants was very stable and showed roughly $3,8 \mathrm{~cm}$.

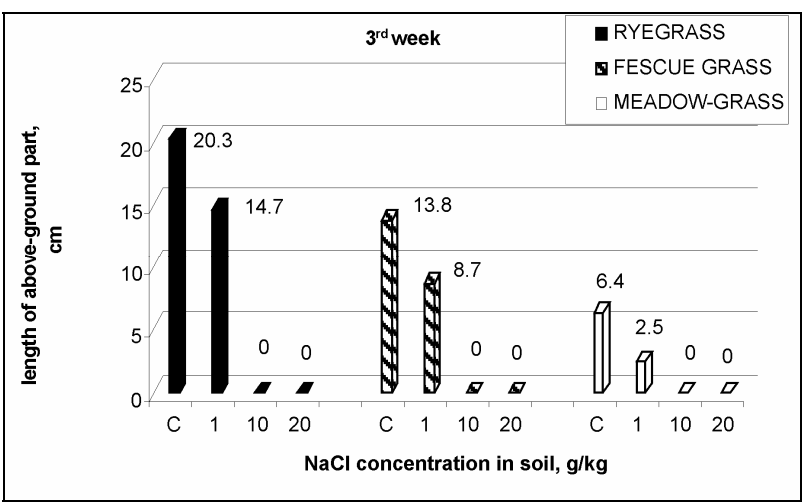

Fig 3. Length of above-ground part of grass vegetation after the $3^{\text {rd }}$ week of growth

22-23 ${ }^{\circ} \mathrm{C}$ temperature was maintained during the $3^{\text {rd }}$ week of study. The length of control ryegrass reached $20,3 \mathrm{~cm}$, that of fescue grass $-13,8 \mathrm{~cm}$ and of meadowgrass $-6,4 \mathrm{~cm}$. Compared to the control length, the length of the above-ground part of ryegrass in the soil with $1 \mathrm{~g} / \mathrm{kg} \mathrm{NaCl}$ content showed the difference of 1,4 times, like on the $2^{\text {nd }}$ week, that of fescue grass 1,6 times and of meadow grass $-2,6$ times. We can see that experimental plants have not germinated in the soil having contamination concentration of $10 \mathrm{~g} / \mathrm{kg}$ and $20 \mathrm{~g} / \mathrm{kg}$ (Fig 3).

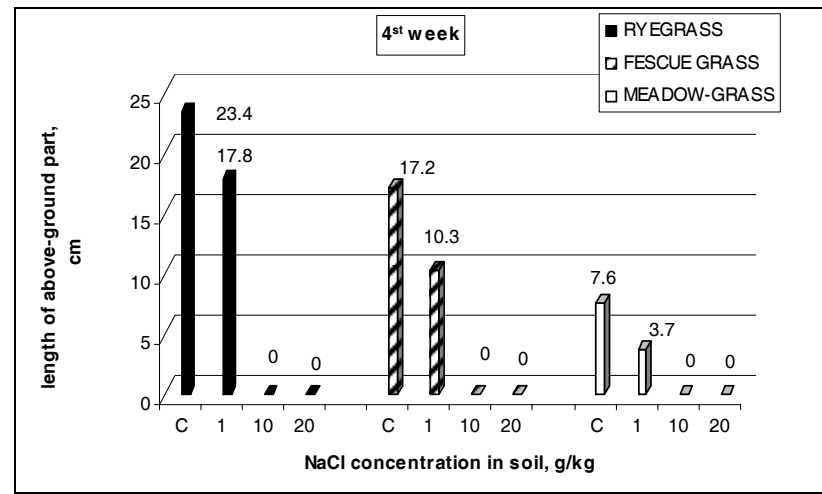

Fig 4. Length of above-ground part of grass vegetation after the $4^{\text {th }}$ week of growth

During the $4^{\text {th }}$ study week $22{ }^{\circ} \mathrm{C}$ temperature was maintained in the room. The plants seeded in soil contaminated with $\mathrm{NaCl}$ had the following lengths: ryegrass $23,4 \mathrm{~cm}$, fescue grass $-17,2 \mathrm{~cm}$, meadow-grass $-7,6 \mathrm{~cm}$. Compared to the control length, the length of the aboveground part of ryegrass in the soil with $1 \mathrm{~g} / \mathrm{kg} \mathrm{NaCl}$ content showed the difference of 1,3 times, that of fescue grass - 1,7 times, of meadow-grass - 2,1 times (Fig 4).

After 4 weeks of growth the length of the aboveground part of ryegrass control plants, compared to the plants seeded in soil contaminated with $1 \mathrm{~g} / \mathrm{kg} \mathrm{NaCl}$, showed the difference of 1,4-2,6 times, that of fescue grass - 1,6-2,5 times, of meadow-grass - 2,1-2,6 (germinated on $2^{\text {nd }}$ week of study).

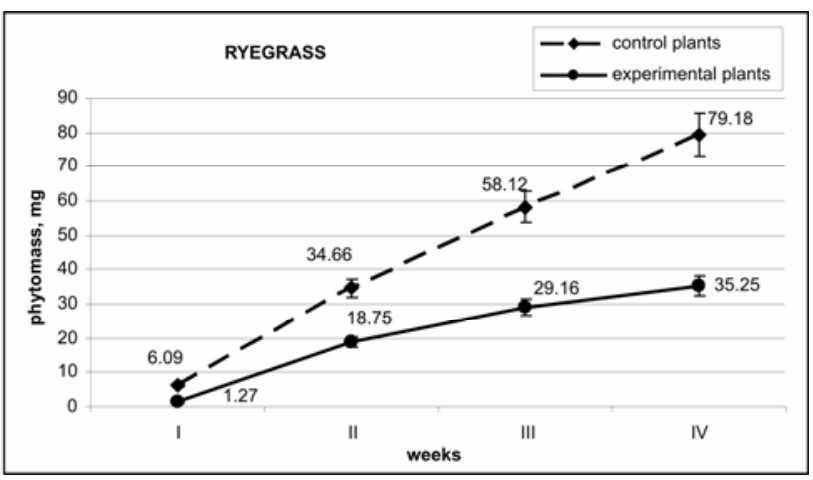

Fig 5. Phytomass of perennial ryegrass after 4 weeks of growth

After 1 week of growth control perennial ryegrass had the phytomass of $6,09 \mathrm{mg}$, and the ryegrass in soil containing $1 \mathrm{~g} / \mathrm{kg}$ of $\mathrm{NaCl}-1,27 \mathrm{mg}$. The difference between the phytomass of ryegrass in soil contaminated with $\mathrm{NaCl}$ and control plants was 4,8 times. When on the $2^{\text {nd }}$ week of study the temperature in the laboratory rose up to $22-23{ }^{\circ} \mathrm{C}$, there were obvious changes in plant phytomass as well as in the length of the above-ground part. After the $2^{\text {nd }}$ week the phytomass of control ryegrass amounted to $34,66 \mathrm{mg}$, and of those in soil contaminated with $\mathrm{NaCl}-$ to $18,75 \mathrm{mg}$. After the $2^{\text {nd }}$ week the phytomass of control ryegrass plants was 1,8 times bigger than that of experimental plants, after the $3^{\text {rd }}$ week this difference reached 2,0 times and after the $4^{\text {th }}$ week 2,24 times. Thus, the biggest difference in the phytomass of control and experimental plants was recorded after the $1^{\text {st }}$ week ( 4,8 times), and the smallest - after the $2^{\text {nd }}$ week (1,8 times) (Fig 5).

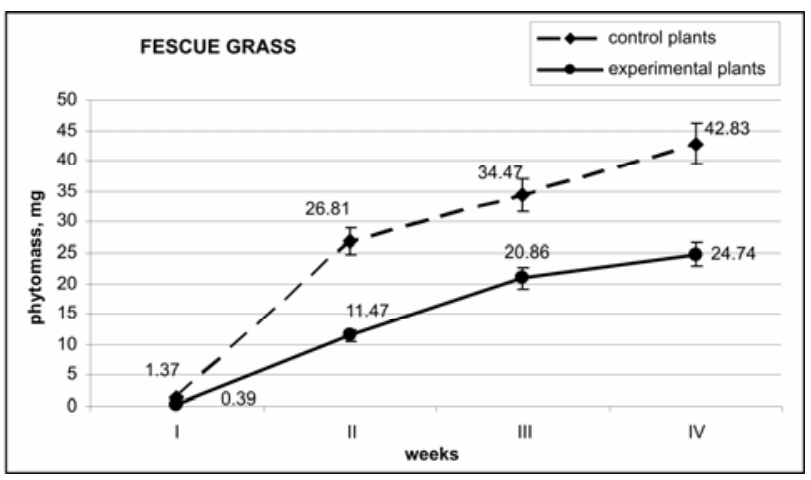

Fig 6. Phytomass of fescue grass after 4 weeks of growth

The largest increase in the phytomass of fescue grass was recorded after the $2^{\text {nd }}$ week of growth: $26,81 \mathrm{mg}$ of control plants, and $11,47 \mathrm{mg}$ of plants in soil contaminated with $1 \mathrm{~g} / \mathrm{kg}$ of $\mathrm{NaCl}$. The smallest difference between the phytomass of control fescue grass plants and experimental plants was recorded after the $3^{\text {rd }}$ week of study (1,6 times), and the biggest - after the $1^{\text {st }}$ week (3,5 times) (Fig 6). 


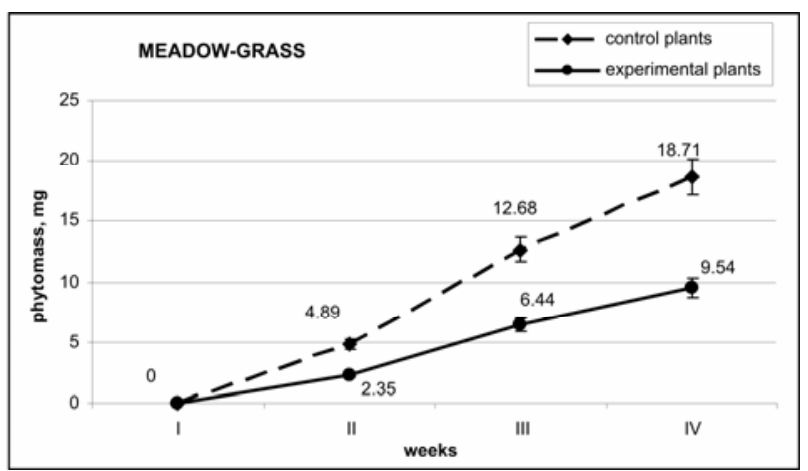

Fig 7. Phytomass of meadow-grass after 4 weeks of growth

As the diagram shows, the results of meadow-grass phytomass are given only from the $2^{\text {nd }}$ week because meadow-grass germinated only on the $2^{\text {nd }}$ week of study. Over the entire period of growth meadow-grass had the smallest phytomass compared to ryegrass and fescue grass. But it was meadow-grass, including both control and experimental plants, the phytomass of which was changing most gradually, what means that the difference in meadow-grass phytomass, when compared to control and experimental plants, was $\sim 2,0$ times over the entire period of investigation (Fig 7).

\section{Conclusions}

1. The analysed species of grass vegetation were seeded in soil contaminated with the following concentrations of sodium chloride $(\mathrm{NaCl}): 1 \mathrm{~g} / \mathrm{kg}, 10 \mathrm{~g} / \mathrm{kg}$ and $20 \mathrm{~g} / \mathrm{kg}$. During the $1^{\text {st }}$ week of study control and experimental ryegrass and fescue grass germinated in the control soil and that with $\mathrm{NaCl}$ contamination concentration of $1 \mathrm{~g} / \mathrm{kg}$. During the $2^{\text {nd }}$ study week meadow-grass also germinated in both control and contaminated (with $1 \mathrm{~g} / \mathrm{kg}$ of $\mathrm{NaCl}$ ) soil. Over 4 weeks experimental plants have not germinated in soils containing $10 \mathrm{~g} / \mathrm{kg}$ and $20 \mathrm{~g} / \mathrm{kg}$ of $\mathrm{NaCl}$.

2. The process of growth was for the most part influenced by the room air temperature. Rapid elongation of the over-ground part of plants took place during the $2^{\text {nd }}$ week of study when the room air temperature rose from $17-18{ }^{\circ} \mathrm{C}$ to $22-23{ }^{\circ} \mathrm{C}$.

3. After 4 weeks of study of all the grass plants in question, perennial ryegrass displayed the largest phytomass in soil with $\mathrm{NaCl}$ contamination concentration of $1 \mathrm{~g} / \mathrm{kg}$, which was $35,2 \mathrm{mg}$. The smallest one was that of meadow-grass - only $9,5 \mathrm{mg}$.

4. During investigation it was perennial ryegrass again that reached the biggest length of the above-ground part in soil with $\mathrm{NaCl}$ contamination concentration of $1 \mathrm{~g} / \mathrm{kg}$. After 4 weeks of growth it amounted to $23,4 \mathrm{~cm}$, while it was meadow-grass again that had the smallest length $-7,6 \mathrm{~cm}$.

5. During experiments it was determined that perennial ryegrass had the highest degree of resistance to toxic impact of salts, since after 4 weeks it was the only of the three experimental species of grass vegetation that started germinating in soil having the contamination concentration of $10 \mathrm{~g} / \mathrm{kg} \mathrm{NaCl}$.

6. The investigation proves that $\mathrm{NaCl}$ content in the soil negatively affects the growing process of grass vegetation, i e it slows down increase of its above-ground part and reduces its phytomass.

7. After 4 weeks the control plants of perennial ryegrass had 3 leaves, and those in soil with $1 \mathrm{~g} / \mathrm{kg}$ of $\mathrm{NaCl}$ contamination -2 leaves. Consequently, salts reduce the amount of leafage, therefore, thinning out of plants caused by salts can be observed even visually.

8. After completing the investigation into toxic impact of road maintenance salt $(\mathrm{NaCl})$ on grass vegetation, it is purposeful to continue it by contaminating soil with $\mathrm{NaCl}$ concentrations from $2 \mathrm{~g} / \mathrm{kg}$ to $8 \mathrm{~g} / \mathrm{kg}$, since the concentration exceeding $10 \mathrm{~g} / \mathrm{kg}$ is toxic to grass plants.

Scientific research is funded under implementation of the COST program activity No 859 "Phytotechnologies to promote sustainable land use and improve food safety" and the project "Contaminants in the system "soil-plants": contaminants transport, accumulation and soil remediation" funded by Lithuanian State Science and Studies Foundation.

\section{References}

1. Storpirštytė, I.; Kazlauskienè, A.; Ščupakas, D. Chloridų koncentracijos sniego dangoje intensyvaus eismo Lietuvos keliu pakelèse tyrimai. Journal of Environmental Engineering and Landscape Management, Vol XII, Supplement 2, Vilnius: Technika, 2004, p 60-66.

2. Oškinis, V.; Kasperavičius, T. Impact of road maintenance salts on water ecosystems according to diatom flora investigation. Journal of Environmental Engineering and Landscape Management, Vol XIII, No 1, Vilnius: Technika, 2005, p 51-55.

3. Zhu, J.-K. Plant salt tolerance. Trends in Plant Science, Vol 6, No 2, 2001, p 66-71.

4. Yokoi, S.; Brestan, R. A.; Hasegawa, P. M. Salt Stress Tolerance of Plants. In: JIRCAS Working Report, 2002, p 25-33.

5. Kayama, M. et al. Effects of deicing salt on the vitality and health of two spruce species, Picea abies Karst., and Picea glehnii Masters planted along roadsides in northern Japan. Environmental Pollution, 124, 2003, p 127-137.

6. Viskari, E.-L.; Karenlampi, L. Roadside Scots pine as an indicator of deicing salt use - a comparative study from two consecutive winters. Water, Air, and Soil Pollution, 122, 2000, p 405-419.

7. Romero-Aranda, R. et al. Physiological and anatomical disturbances induced by chloride salts in sensitive and tolerant citrus: beneficial and detrimental effects of cations. Plant, Cell and Environment, 21, 1998, p 1243-1253.

8. Bañuls, J. et al. Growth and gas exchange parameters of Citrus plants stressed with different salts. Journal of Plant Physiology, 150, 1997, p 194-199.

9. Wilcox, D. A. The effects of $\mathrm{NaCl}$ deicing salts on Sphagnum recurvum $P$. beauv. Environmental and Experimental Botany, Vol 24, Issue 4, 1984, p 295-301.

10. Braun, S.; Flückiger, W. Increased population of the aphid Aphis pomi at a motorway. Part 2. The effect of drought and de-icing salt. Environmental Pollution Series A, Ecological and Biological, Vol 36, Issue 3, 1984, p 261-270. 


\section{DRUSKOS, NAUDOJAMOS KELIU PRIEŽIŪRAI, TOKSINIO POVEIKIO ŽOLINEI AUGALIJAI EKSPERIMENTINIAI TYRIMAI}

\section{P. Baltrėnas, A. Kazlauskienė, J. Zaveckytė}

Santrauka

Augalai aplinkoje patiria daugeli stresų: dèl druskų, sausros, sunkiujų metalų, šalčio. Pasaulyje atliekami keliu priežiūrai naudojamų druskų poveikio įvairių rūšių augalams natūriniai ir laboratoriniai tyrimai. Lietuvoje tokio pobūdžio tyrimai kol kas tera pavieniai.

Straipsnyje pateikti Lietuvoje keliu priežiūrai daugiausiai naudojamos druskos - natrio chlorido $(\mathrm{NaCl})$ toksinio poveikio žolinei augalijai eksperimentinių tyrimų rezultatai. Tyrimai buvo atliekami laboratorinėmis sąlygomis. Tyrimams pasirinktos trys žolinės augalijos rūšys, kuriomis dažniausiai želdomos pakelès: daugiametė svidrè (Lolium perenne L.), tikrasis eraičinas (Festuca pratensis Huds.), pievinė miglè (Poa pratensis L.). Tyrimų metu nustatyta, kad NaCl, patekęs i dirvožemi, turi neigiamos ịtakos žolinès augalijos augimo procesui, lėtina jos antžeminès dalies ir fitomasès prieaugi. Eksperimento metu paaiškejjo, kad atspariausia natrio chlorido toksiniam poveikiui yra daugiametè svidrè.

Prasminiai žodžiai: druska, naudojama kelių priežiūrai, žolinė augalija, toksinis poveikis.

\section{ЭКСПЕРИМЕНТАЛЬНЫЕ ИССЛЕДОВАНИЯ ТОКСИЧНОГО ВОЗДЕЙСТВИЯ НА ТРАВЯНИСТУЮ РАСТИТЕЛЬНОСТЬ СОЛЕЙ, ПРИМЕНЯЮЩИХСЯ ДЛЯ СОДЕРЖАНИЯ ДОРОГ}

\section{П. Балтренас, А. Казлаускене, Й. Завяцките}

Р е $з$ ю м е

Растительность в окружающей ее среде подвергается многочисленным воздействиям солей, тяжелых металлов, жары, холода. В мире проводятся натурные и лабораторные исследования воздействия на растения разных видов солей, применяющихся для содержания дорог. В Литве исследования такого рода пока немногочисленны.

В статье представлены экспериментальные результаты токсичного воздействия на травянистую растительность наиболее часто применяющихся в Литве для содержания дорог солей натрия хлорида $(\mathrm{NaCl})$. Исследования проводились в лабораторных условиях. Для испытаний были выбраны три вида травянистой растительности, чаще всего применяющиеся для озеленения обочин: плевел многолетний (Lolium perenne L.), овсянка обыкновенная (Festuca pratensis Huds.), луговой мятлик (Poa pratensis L.). Наблюдениями установлено, что $\mathrm{NaCl}$, попадая в почву, отрицательно сказывается на процессе жизнедеятельности травянистой растительности, замедляя рост верхней части растения и прирост фитомассы. Наибольшая устойчивость против токсичного воздействия натрия хлорида установлена у плевела многолетнего.

Ключевые слова: соли для содержания дорог, травянистая растительность, токсичное воздействие.

Pranas BALTRÉNAS. Dr Habil, Prof and head of Dept of Environmental Protection, Vilnius Gediminas Technical University (VGTU).

Doctor Habil of Science (air pollution), Leningrad Civil Engineering Institute (Russia), 1989. Doctor of Science (air pollution), Ivanov Textile Institute (Russia), 1975. Employment: Professor (1990), Associate Professor (1985), senior lecturer (1975), Vilnius Civil Engineering Institute (VISI, now VGTU). Publications: author of 13 monographs, 24 study-guides, over 320 research papers and 67 inventions. Honorary awards and membership: prize-winner of the Republic of Lithuania (1994), a corresponding Member of the Ukrainian Academy of Technological Cybernetics, a full Member of International Academy of Ecology and Life Protection. Probation in Germany and Finland. Research interests: air pollution, pollutant properties, pollution control equipment and methods.

Agnė KAZLAUSKIENE். Master, doctoral student (since 2003), Dept of Environmental Protection, Vilnius Gediminas Technical University (VGTU).

Master of Science (environmental protection engineering) (2002), Bachelor of Science (environmental engineering) (2000), VGTU. Research interests: environmental protection, environmental pollution with road maintenance salt.

Jolita ZAVECKYTÉ. Master student (since 2004), Dept of Environmental Protection, Vilnius Gediminas Technical University (VGTU).

Bachelor of Science (environmental engineering), 2004, VGTU. Research interests: road salt contamination. 